\title{
降水後の人工被覆面からの蒸発量予測簡易モデルの構築 ESTABLISHMENT OF SIMPLIFIED MODEL TO PREDICT EVAPORATION FROM THE BUILDING SURFACE AFTER PRECIPITATION
}

\author{
萩島 理*, 谷本 潤**, 片山忠久***, 月松孝司 $* * * *$ \\ Aya HAGISHIMA, Jun TANIMOTO, Tadahisa KATAYAMA \\ and Koji TSUKIMATSU
}

\begin{abstract}
The authors performed the field measurement to evaluate the evaporation ratio after precipitation at the concrete slab and the painted wall of the building for six months.And they proposed the simplified method to predict the evaporation ratio of the artificial surfaces after precipitation based on the measurement data. Following conclusions were reached.

1.Thermal effect of the evaporation at the vertical wall after precipitation was negligibly small compared with that at the horizontal concrete slab.

2.Transitional variation of the evaporation ratio at the horizontal concrete slab after the precipitation was expressed as: $r e=r_{c_{t}=0} \exp (-a t)$. 3.The parameter $a$ could be expressed as the function of the initial evaporation ratio $r_{e, r=0}$ and the averaged differential of humidity.
\end{abstract}

key wards : artificial surface, evaporation ratio, field measurement, simplified model, precipitation 人工被覆面、蒸発比、実測、簡易モデル、降水

\section{1. 目的}

現在、ヒートアイランドの要因解析をはじめとする都市スケー ルでの伝熱問題を取り扱う場合、表面からの蒸発を考慮するのは 土壤、植生等の自然地被面のみであり、アスファルトやコンクリ 一ト等の人工被覆面では降水や結露により過渡的に濡れ面になる ことを無視し、常に気乾状態であると仮定した計算を行うのが一 般的である”。

これに対して、夏季の屋外暑熱環境やヒートアイランド現象の 緩和を目的として、空隙率を調整することによって保水性を飛躍 的に高めたレンガ 2)、湿潤舗装システム ングレンガかなど、近年、人工被覆面に蒸発泠却効果を付与しよ うという取り組みがなされている。人工被覆面の中でも多孔質材 料が都市構成面に占める割合は非常に高いことから、今後は都市 スケールの伝熱問題においても、降雨や撒水等による人工被覆面 の蒸発冷却効果を定量化していくことが必要となろう。

人工被覆面からの蒸発量を定量化するための物理モデルとして は、建築壁体内部の湿気移動に関して、従来から熱水分同時移動 方程式に基づく解析、物性值の同定が精力的に行われてきており 5、たとえば降水を考虑した室内熱負荷計算理論もすでに確立され ているの。また、これらの熱水分同時移動解析モデルを都市キャ
ノピーモデルと連成し、パッシブクーリングレンガのヒートアイ ランドに対する緩和効果の定量化を試みた研究もなされている》。 この熱水分同時移動方程式は、壁体内の洋細な含水率分布を予 測することが可能なため、特に長期間にわたる壁体内結露や地下 室の湿気特性解析等において有用な解析手法として広く用いられ ている。一方、建築、都市大気、土壤、植生を含めた連成系の伝 熱モデルにおいては、人工被覆面からの蒸発が有意となるのは、 降水や撒水後 1 日程度の短期間であると考えられるから、そのよ うな過渡的表面蒸発量を予測する際には、壁体内部の含水率性状 の影響は相対的に小さいであろう。従って、このような場合には、 壁体内部の含水率分布を考慮することなく表面蒸発量を簡易に推 定できるモデルが、熱水分同時移動方程式を詳細に解く方法に対 するオルタナティブとして有用であろう。

以上の背景から、筆者らは、降水直後 1 日程度の短期の人工被 覆面からの蒸発量予測簡易モデルの構筑を目的として、実在建物 外表面熱収支の長期測定を行い、蒸発比減衰の動特性を簡易なモ デルで表現する目途を得たので、ここに報告する。

\footnotetext{
* 九州大学大学院総合理工学研究院 助手 $\cdot$ 工修

** 九州大学大学院総合理工学研究院 助教授・工博

*** 九州大学大学院総合理工学研究院 教授.工博

**** 九州大学大学院総合理工学府 大学院生
}

Research Assoc., Interdisciplinary Graduate School of Engineering Sciences, Kyushu Univ., M. Eng.

Assoc. Prof., Interdisciplinary Graduate School of Engineering Sciences, Kyushu Univ., Dr. Eng.

Prof., Interdisciplinary Graduate School of Engineering Sciences, Kyushu Univ., Dr. Eng.

Graduate Student, Interdisciplinary Graduate School of Engineering Sciences, Kyushu Univ. 


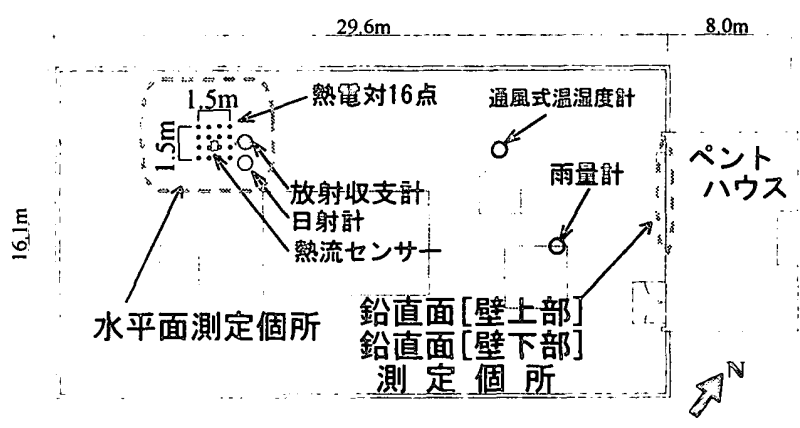

(a) 測定場所の平面図

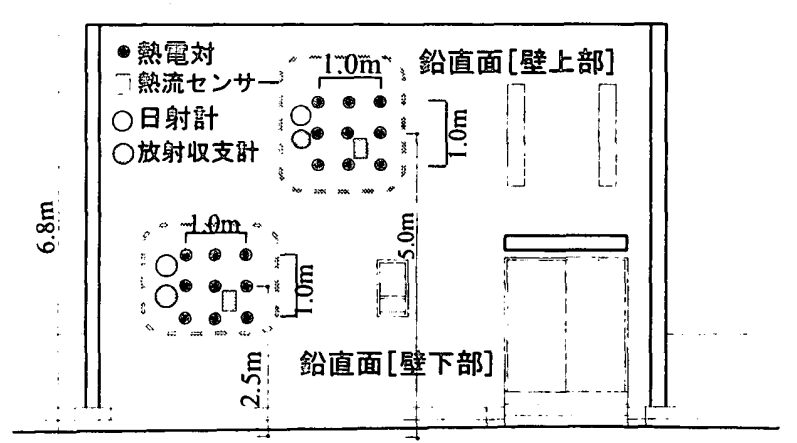

(b) ペントハウス立面図

图 1 測定場所の概要及び測定機器設置状況

\section{2. 測定概要}

\section{2-1 㵋定場所および測定方法}

6 階建て建物の屋上スラブ面（RC+防水コンクリート鏝仕上げ B 種、スラブ勾配 1/50、伸縮目地@3000 mm、以下水平面とする) とペントハウス鉛直壁面（RC+複層吹付塗材 $\mathrm{E}$ 吹き付け、上下 2 力所、以下、鉛直面[壁上部],鉛直面[壁下部]とする）について表 面熱収支に関する測定を行った。

測定期間は 1998 年 5 月から 1998 年 11 月までの計 6 ヶ月間であ る。測定機器の故障や台風等の気象条件の悪化による久測日を除 く計 157 日の熱収支データを得ている。測定項目及び測定機器を 表 1 に、測定場所の概要及び測定機器設置状況を図 1 に示す。

各測定箇所では、対流、蒸発を除く熱収支成分（伝導熱量、放 射収支量）と表面温度、全天日射量、近傍風速を 1 分間隔で自動 測定し、解析には 5 分間の平均值を用いている。表面温度は水平 面 16 点、鉛直面[壁上部],[壁下部]各 9 点について測定し、解析に はそれらの平均值を用いている。尚、測定に先立ち赤外線放射力 メラで対象面の放射温度分布が充分に小さいことを確認している。

\section{2-2 蒸発比の推定方滛}

人工被覆面の表面における熱収支式は以下のように表せる。

$$
\begin{aligned}
& \mathbb{R}_{\text {net }}=C V+C D-l \cdot E V \cdots \cdots \cdot \cdot(\mathbb{1}) \\
& C V=\alpha \cdot\left(T_{\text {air }}-T_{\text {surf }}\right) \cdots \cdots(2)
\end{aligned}
$$

$R_{n e:}$ 放射収支舅 $\left[\mathrm{W} / \mathrm{m}^{2}\right], C V$ :対流熱伝達量 $\left[\mathrm{W} / \mathrm{m}^{2}\right], C D$ :伝導熱量 $\left[\mathrm{W} / \mathrm{m}^{2}\right]$, $E V:$ 蒸発量 $\left[\mathrm{kg} / \mathrm{m}^{2} \cdot \mathrm{s}\right], l:$ 相変化熱 $[\mathrm{J} / \mathrm{kg}], \alpha$ : 対流熱伝達率 $\left[\mathrm{W} / \mathrm{m}^{2} \mathrm{~K}\right], \mathrm{T}_{\text {air }}$ 空気 温度 $[\mathrm{K}], \mathrm{T}_{\text {sur }}$ : 表面温度 $[\mathrm{K}]$

(1)式中の蒸発量 EV を蒸発比を用いて表現すると次式となる。

\begin{tabular}{|c|c|c|}
\hline 測定項目 & 測定機器 & 測定点数 \\
\hline 伝導熱流 & 熱流也’サ-(英弘精機(侏)MF-9) & \multirow{3}{*}{$\begin{array}{l}\text { 水平面, 鉛直[壁上 } \\
\text { 部], 鉛直面[壁下 } \\
\text { 部]各 } 1 \text { 点 }\end{array}$} \\
\hline 放射収支量 & 放射収支計(英弘精機侏|MF-11) & \\
\hline 入射日射量 & 簡易日射計(英弘精機侏)MS-100) & \\
\hline 表面温度 & T-CC 熱電対 $0.3 \mathrm{~mm}$ & $\begin{array}{c}\text { 水平面 } 16 \text { 点, } \\
\text { 敛直面上下各 } 9 \text { 点 }\end{array}$ \\
\hline 近傍風速 & \multirow{2}{*}{ 熱式風速計(英弘精機侏IRDUM) } & \multirow{2}{*}{$\begin{array}{c}\text { 水平面 } 1 \text { 点, 鉛直 } \\
\text { 面[壁下部] } 1 \text { 点 } \\
\mathrm{H}=0.3 \mathrm{~m}\end{array}$} \\
\hline 近傍風向 & & \\
\hline 空気温度 & \multirow{2}{*}{$\begin{array}{c}\text { 通風式温湿度㖕（英弘精機侏 } \\
\text { MH-011PS）温度:白金抵抗式,湿 } \\
\text { 度:静電容量式 }\end{array}$} & \multirow{2}{*}{$\begin{array}{c}1 \text { 点 } \\
H=1.2 \mathrm{~m}\end{array}$} \\
\hline 相対湿度 & & \\
\hline 降水量 & 転倒マス式雨量計 & 1 点 \\
\hline
\end{tabular}

表 1 測定項目及び測定機器

$$
E V=r e \cdot \frac{\alpha}{c_{p m}} \cdot\left(X_{s a t}\left(T_{s u r f}\right)-X_{a i r}\right) \cdots \cdot(3)
$$

$r e:$ 蒸発比[-], $c_{p m}$ 湿り空気比熱 $[\mathrm{J} / \mathrm{kg} \cdot \mathrm{K}], X_{s z r}\left(T_{\text {sur }}\right)$ :表面温度 $T_{\text {surf }}$ に対する 飽和絶対湿度 [kg/kg'], $X_{\text {air }}$ :空気絶対湿度 $\left[\mathrm{kg} / \mathrm{kg}^{\prime}\right]$

晴天が 2 日以上連続している日（以下、連続晴天日とする）に おいては、蒸発量はゼロと見なせるので、放射収支量, 伝導熱流の 実測值を(1)式に代入して、残差項として対流成分を得ることがで きる。次に、得られた対流成分と表面温度、気温の実測值を(2)式 に代入し、対流熟伝達率を算出する。以上り結果から得られた対 流熱伝達率と近傍風速の関係から対流熱伝详率の推定式を求める。 尚、推定精度を上げるため、放射収支量の大小及び対流熱流束の 向きによって場合分けをした上で月別に推定式を求めている。

降水翌日の晴天日について、連続晴天日のデータより得られた 上述の対流熱伝達率の推定式から対流成分を求め、残差項として 蒸発量と蒸発比を求める。また、晴天日の昼間にホースで撒水し た直後についても、同様の手法で蒸発量、蒸発比を求めている。

\section{3. 測定結果}

\section{3-1 対流熱伝達事の推定式}

対流熱伝達率の推定式の精度を確認するため、晴天が連続した 1999/8/19-8/22 について、対流熱伝達率の推定式を使って対流成分 を算出し、表面熱収支に残留する誤差を求めた結果を図 2 に示す。 多少の誤差は認められるが、日中については降水直後の蒸発潜熱 の過渡応答を求めるには充分な精度が得られていると思われる。

\section{3-2 䕩発比の時変動特性}

推定された蒸発潜熱量及び蒸発比の時変動特性を水平面及び鉛 直面[壁下部]について図 3 に示す。(a)は降水翌日の晴天日の一例 として 1998/9/24,25、(b)は連続晴天日の日中に人工的に撒水した 1998/10/10 のデータである。尚、蒸発比のプロットは日射の影響 で蒸発比の推定值が安定する時刻以降から蒸発が終了したと思わ れる時刻まで示している。

水平面については、自然降水、人工撒水ともに蒸発比が 1 近傍 の值から徐々に減衰していく様子が見て取れる。

これに対して、鉛直面については自然降水の場合、蒸発比はほ ぼ 0 に近い值を示している。また、人工撒水後り場合は、自然降 


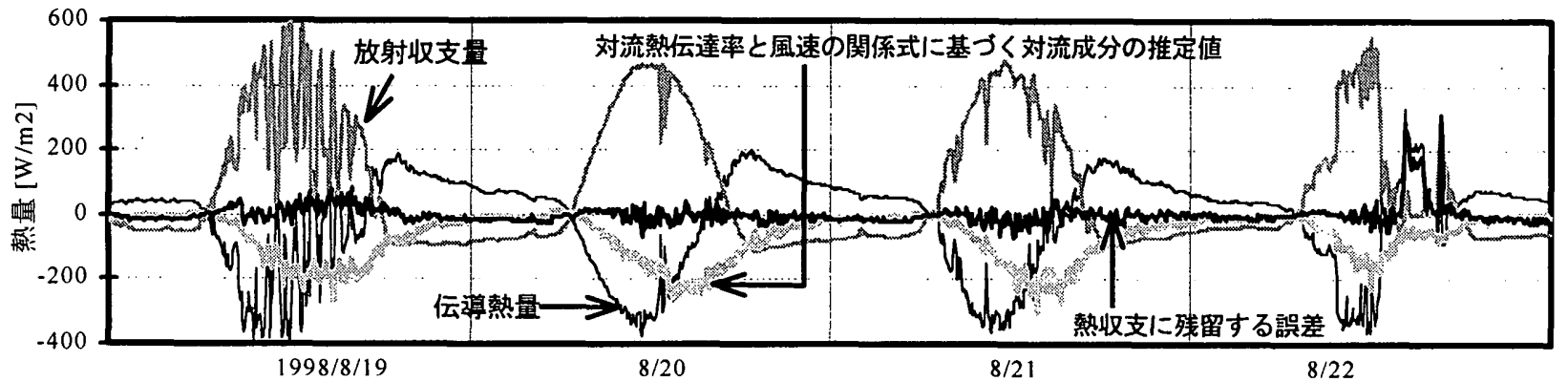

図 2 連続晴天日における水平面熱収支の経時変化（スラプ面に入射する向きをプラスと表吝）
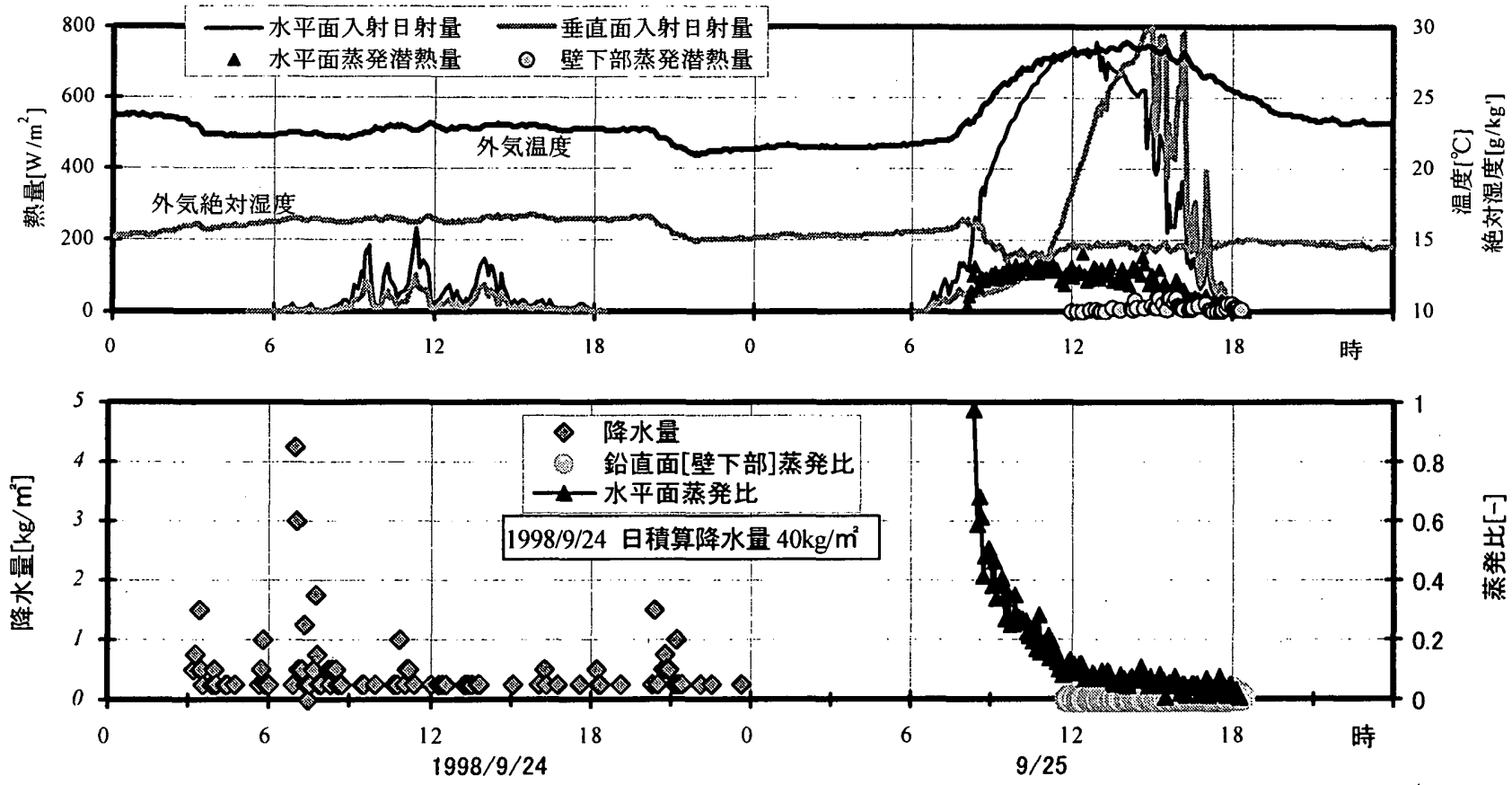

図 3(a) 降水翌日の蒸発潜熱量及び蒸発比の経時変化(1998/9/24,9/25)

水に比して明らかに大きな值を示しているが、そ れでも蒸発比の初期值 (以下、初期蒸発比とする) は 0.2 前後と水平面に比べては小さく、蒸発比の 減衰も早い。この理由としては次の 2 点が考えら れる。第 1 点は、鉛直壁面上に保持され蒸発に有 効に作用する水分量（鉛直面への正味の降水量） は水平面に比べて著しく小さいこと、第 2 点は今 回測定対象とした水平面が多孔質材料であるコン クリートの鏝仕上げであるのに対して、鉛直面が 撥水性の複層材塗り仕上げであることである。

以上より、鉛直壁面では自然降水直後の過渡的 状況にあっても鉛直面からの蒸発の効果は総じて 小さいと見て差し支えないと考えられよう。
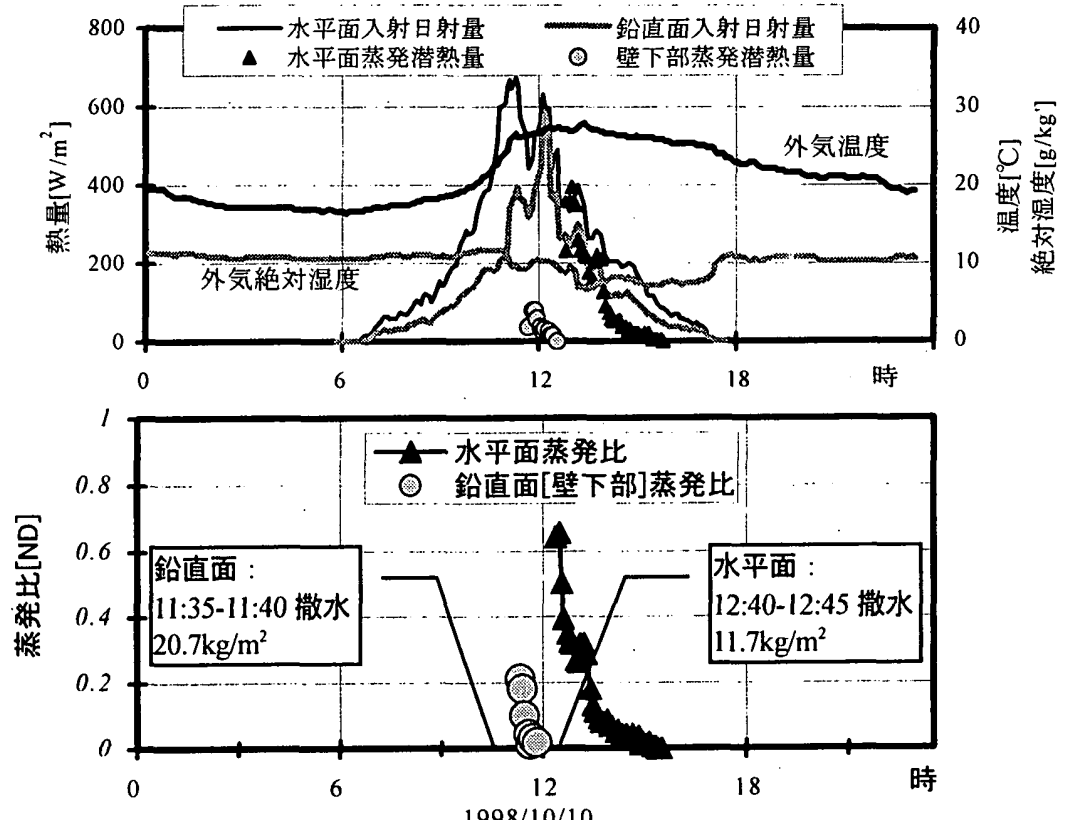

$1998 / 10 / 10$

図 3(b) 連続晴天日に人工撒水した場合の

蒸発潜熱量及び蒸発比の経時変化(1998/10/10) 


\section{4. 考察}

\section{1 蒸発比の減衰特性}

鉛直面については前述の通り自然降水による蒸発泠却効果は無 視しうると考え、水平面についてのみ考察を行う。尚、蒸発比の 推定精度が覀くなる夜間のデータは以下の解析には用いていない。

安定的に蒸発比を推定することができた全 10 日間の蒸発比時 変動特性を図 4 に示す。横軸の「経過時間(蒸発)」は、蒸発比の 推定值が安定し、かつ減衰が開始する時刻を起点として定義して いる。本来ならば雨の降り止んだ時刻を起点とするべきであるが、 降雨終了時刻が夜間であったり、日中でも放射収支量がきわめて 小さいデータが多く、対流成分の推定誤差が相対的に大きくなり、 適切な蒸発量、蒸発比の值を得ることはできなかったためである。

そのため、経過時間(蒸発)がゼロの起点における蒸発比（以下、 初期蒸発比と呼ぶ）は、日によって 0.2〜1.0の異なる值を示して いる。これは、降水終了時刻から蒸発比の安定する時刻までの経 過時間（以下、「経過時間(降水)」と呼ぶ）と降水後から蒸発比の 推定されるまでの気象要素が、データによって異なっていること が原因と考えられる。尚、ここで「降水」とは、時間秝算降水量 $0.5\left[\mathrm{~kg} / \mathrm{m}^{2} \cdot \mathrm{h}\right]$ 以上の場合としている。

いずれのデータも蒸発比は起点から 2 時間で急激に減少し大略 exponential 形の減衰傾向を示しており、初期蒸発比が大きいほど 減衰も激しくなっている。

次に減衰が急激に起こる起点から 2 時間の初期減衰特性を見る ため、(蒸発比/初期蒸発比)の対数の経時変化を調べた。その結果 を図 5 に示す。その経時変化は多少のぶれはあるもののほぼ一定 の傾きで、自然降水日より撒水日の方が大きい傾きを示している。

\section{4-2 蒸発比隇衰のモデル化}

以上より蒸発比の初期 2 時間の減衰モデルを次式で表現する。

$r e(t)=r e_{t=0} \cdot \exp (-a t)$

但し、 $r e_{t=0}$ : 初期蒸発比[-], $t:$ 経過時間(蒸発)

(4)式中の a は蒸発比減衰の激しさを表すパラメーターで、図 5 の傾きの絶対値に相当する。この a は、気温、全天日射量、絶対 湿度など蒸発を促す気象要素の影響を受けていると考えられる。

一方、起点から 2 時間以降の蒸発比については、図4 から明ら かなように、もはやその值は充分に小さいので、䉕定的に日没後

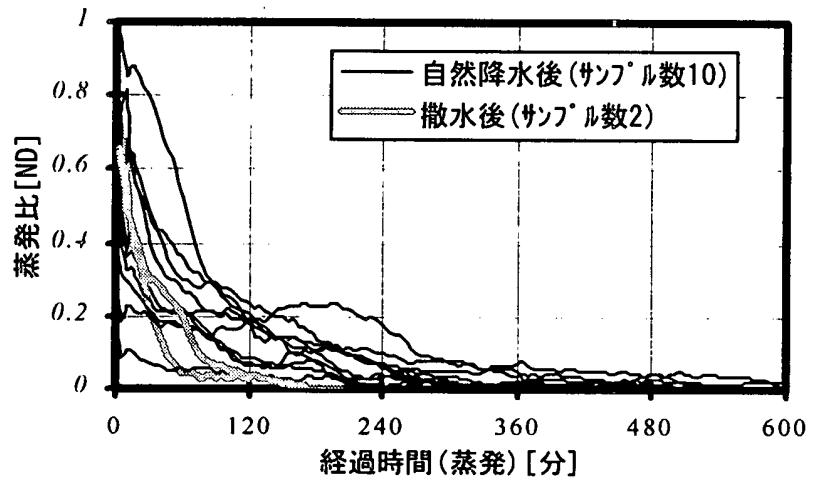

図 4 蒸発比時変動特性

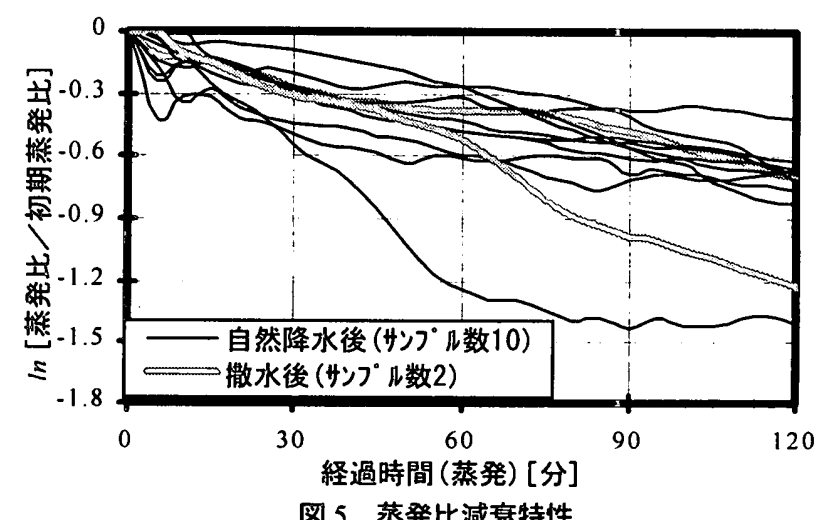

図 5 蒸発比減衰特性

に蒸発比 0 になるとして線形内挿補間することとする。

これまでの考察を整理すると、(4)式中の $\boldsymbol{r}_{t-0}$ と $a$ を気象デー夕 等の既知データから推定することが出来れば、蒸発比減衰モデル は閉じたことになる。

次に、rer-0 $a$ を目的変数とし気象要素を説明変数とした重回 帰分析を行った結果を表 2 に示す。説明変数として、初期蒸発比 については経過時間(降水)と経過時間 (降水)の飽差の平均値、(4) 式中の $a$ については初期蒸発比と減衰後 2 時間の飽差の平均值を 取り上げている。飽差とは表面温度に対する飽和絶対湿度と空気 絶対湿度の差であるが、通常表面温度は未知変量であるため、飽 差を説明変数に用いた定式化の場合は線形の伝熱モデルに組み込 むことが難しい。そこで、新たに「等価飽差」を定義し、説明変 数として用いた場合の結果を併せて示す。等価飽差とは、対流熱 伝達率 23.2[W/ $\left.\mathrm{m}^{2}\right]$ 、日射吸収率 1 とした相当外気温度に対する飽 和絶対湿度と空気絶対湿度の差である。等価飽差は気温、全天日

表 2 重回帰分析結果

\begin{tabular}{|c|c|c|}
\hline 目的関数 & 重回帰式 & 重相関係数 \\
\hline \multirow{2}{*}{$\begin{array}{c}\text { 初期蒸発比 } \\
r_{e, t=0} \\
\text { サンプル数 } 9\end{array}$} & $\begin{array}{l}r_{e, t=0}=-6.48 \times 10^{-4} \cdot X 1-1.28 \times 10^{-2} \cdot X 2+1.00 \cdots \cdots \cdots(5) \\
X I: \text { 経過時間(降水)[分], } X 2: \text { 経過時間(降水)中の飽差の平均値 }\left[\mathrm{g} / \mathrm{kg}^{\prime}\right]\end{array}$ & $R=0.8578$ \\
\hline & $\begin{array}{l}r_{e, t=0}=-6.40 \times 10^{-4} \cdot X 1-1.29 \times 10^{-2} \cdot X 3+1.00 \cdots \cdots \cdots(6) \\
X I: \text { 経過時間(降水)[分], } X 3: \text { 経過時間(降水)中の等価飽差(空気温度)の平均値[ } \mathrm{g} / \mathrm{kg}]\end{array}$ & $R=0.8586$ \\
\hline \multirow{2}{*}{$\begin{array}{l}\text { (4)式ゆの } a \\
\text { サンプル数 } 12\end{array}$} & 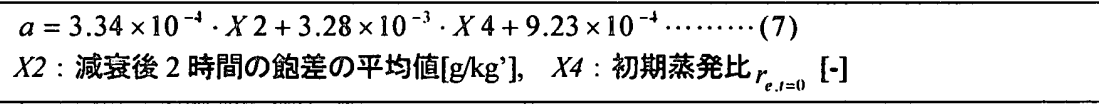 & $R=0.8534$ \\
\hline & $\begin{array}{l}a=9.37 \times 10^{-3} \cdot X 5+1.44 \times 10^{-3} \cdot X 4+4.46 \times 10^{-3} \cdots \cdots \cdots(8) \\
X 5: \text { 減琵後 } 2 \text { 時間の等価飽差(相当外気温度)の平均値 }\left[\mathrm{g} / \mathrm{kg}^{\prime}\right], X 4: \text { 初期蒸発比 } r_{e, t=0}[-]\end{array}$ & $R=0.6258$ \\
\hline
\end{tabular}



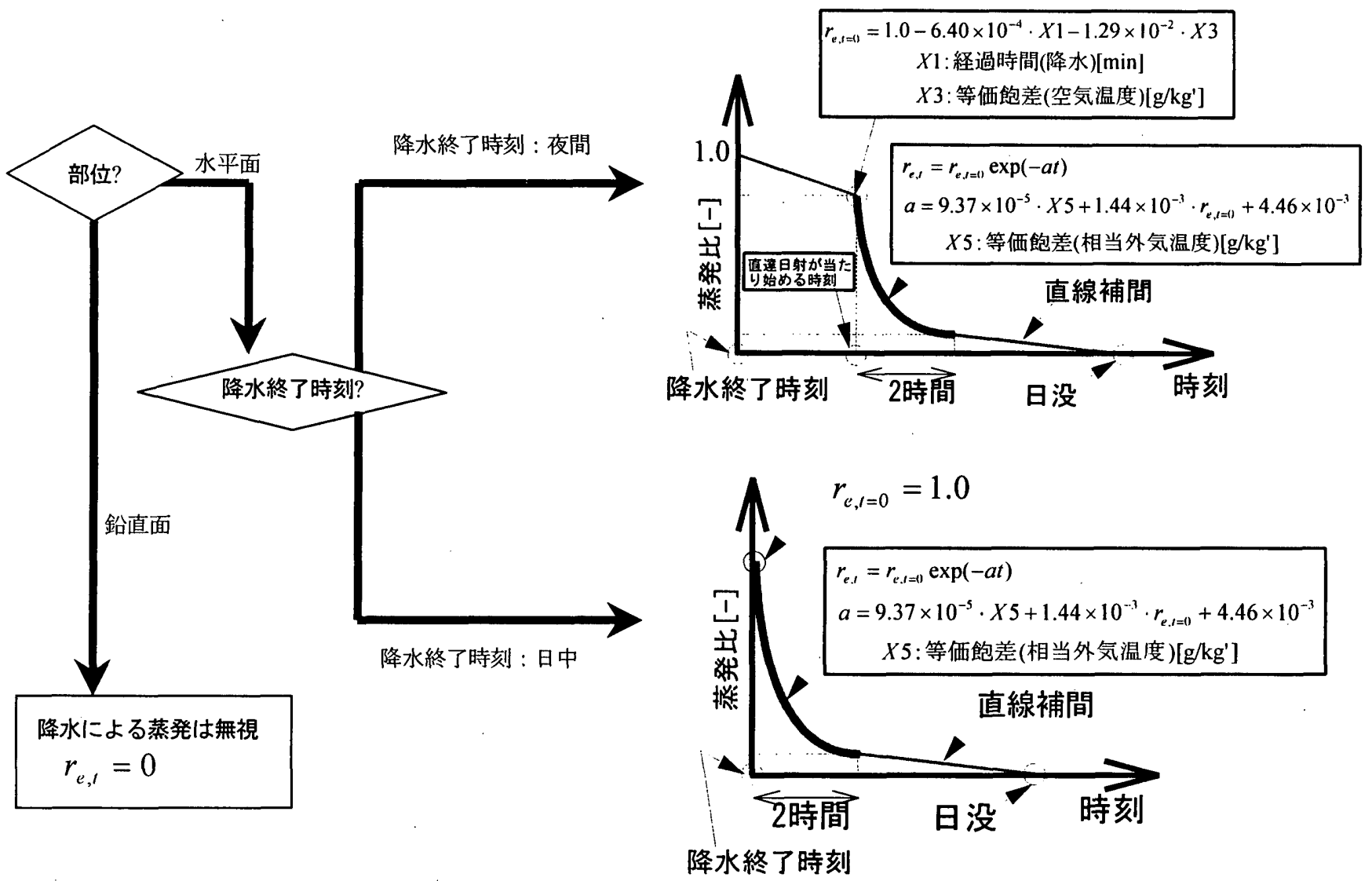

図 6 人工被覆面における蒸発減衰モデル

射量、絶対湿度等の影響を含んだ蒸発のし易さ を表すもので物理的な意味はないが、未来の值 であっても境界条件として付与されることを前 提にすれば気象要素から簡易に算出できるもの である。

初期蒸発比については、経過時間(降水)X1、 飽差 X2、等価飽差 X3 0)係数はいずれもマイナ ス0)符号となっており、初期蒸発比を小さくす る向きに働く、という物理的に妥当なものであ る。サンプル数は少ないながらも(5)(6)式ともに 重相関係数は 0.8 以上の值を示している。

(4)式中の) a については、飽差を説明変数に採

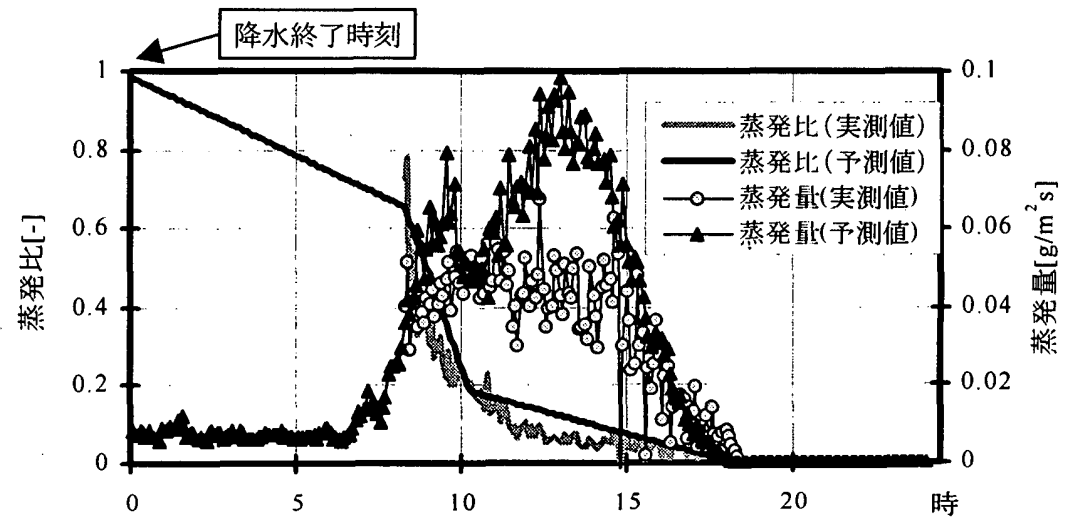

図 7 簡易モデルによる蒸発比,蒸発量の予測値と実測値の比較(1998/9/25) 用した(7)式の重相関保数が 0.8 を越えているの に対して、等価飽差を説明変数に採用した(8)式は 0.62 と低い值に なっている。(7)式を用いた方が回州の精度は向上するが、本来表 面温度は未知変量であり、線形計算を前提とすれば(6)式の方が使 いやすい。

以上をまとめて図 6 に人工被覆面蒸発比の减衰モデルを示す。

\section{5. 蒸発此の減衰モデルを用いた計算結果と実测結果の比較}

本実測データの気象条件を用いて降水後の蒸発量及び蒸発比を 簡易モデルによりトレースした結果を図 7 に示す。蒸発比の計算 值は、午前 8 時に約 0.650 の值を示した後に急激に減少し、実測值 と概权類似のトレンドとなっている。一方、蒸発量については、

蒸発比の减衰特性を exponential 形で表現した午前 8 時から 10 時の間については、実測值と計算值は概ね一一致しているが、蒸発 比を線形補完した午前 10 時以降については、表面温度が上昇し 飽差が大きくなる 12 時から 15 時の間で、蒸発比推定の僅かの誤 差が蒸発量では無視し得ぬ誤差となっている。

以上より、今後蒸発量予測モデルの精度を高めるためには、減 衰 2 時間以降に関しても適用可能なモデルの検討を行う必要があ ると思犼る。 


\section{6. 莍と好}

実在建物外表面熱収支の長期測定を行い、降水後及び撒水後の 人工被覆面からの蒸発量及ひ蒸発比の推定を行った。また、得ら れた実測データからコンクリート水平面における散水、降水後 2 時間の蒸発比減衰特性を次式で表現した。

$r e(t)=r e_{t=0} \cdot \exp (-a t)$

$r_{e, t=0}=-6.40 \times 10^{-4} \cdot X 1-1.29 \times 10^{-2} \cdot X 3+1.00$

$a=9.37 \times 10^{-5} \cdot X 5+1.44 \times 10^{-3} \cdot X 4+4.46 \times 10^{-3}$

$X I:$ 経過時間(降水)[分], $X 3:$ 経過時間(降水)中の等価飽差(空気温度) の平均値 $\left[\mathrm{g} / \mathrm{kg}^{\prime}\right], X 5$ : 減衰後 2 時間の等価飽差(相当外気温度)の平均

值 $[\mathrm{g} / \mathrm{kg}], X 4:$ 初期蒸発比 $r_{c . t=0}[-]$

屋上スラブコンクリート面、吹き付け塗り材仕上げの鉛直壁面 はいずれも吸水性が低いため、表面の仕上げ、勾配、目地配置等 が表面蒸発量に与える影響は少なくないと思われる。しかし、今 回の測定対象面はいずれも建築工事の一般的な標淮仕様書に規定 されている仕上げ状況であり、結果自体の有意性が失われること はないと判断している。この簡易予測式の特徴及び適用範囲を以 下に列記する。

1. 降水後 2 時間という時間及び予測式中の係数は、表面の材料、

形状、勾配等により変化することが予測される。

2. 降水後乾燥に数日を要する吸水性の高い素材には適用出来 ない。

尚、提案した簡易モデルは蒸発比の動特性を概ね表現している が、飽差の大きくなる時間帯においては、わずかな蒸発比の予測 誤差が、蒸発量では大きな誤差となる場合があるため、注意を要 する。

次稿では、他の代表的な人工被覆面として、アスファルト舗装 面、アスファルト防水面についても同様の検討を行うとともに、 降水終了後 2 時間以降にも拡張可能な改良モデルの提案を行う予 定である。

\section{【謝辞】}

本研究を行うにあたり、九州大学大学院総合理工学研究科大気 海洋環境システム専攻教室には実測場所を長期にわたり提供して

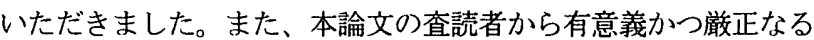
ご助言を受け、論文の体裁を整える事ができました。ここに記し て樑く感謝の意を表します。

本研究の一部は文部省科研費。地域連携推進研究「地域熱供給 計画支援都市熱環境シミュレーターの開発」（代表 片山忠久,課 題番号 11792017）による。
『注距 1』水平面降水量と鉛直壁面に入射寸る正味の降水量との 比較を付図に示す。尚、壁面入射正味降水量の算出は文献 8)に拠 った。鉛直壁面に直接撒水した場合を除いて正味降水量は著しく 小さい。

【注䟕 2】降水終了後及び撒水後に数回観察した結果によると、 コンクリート水平面が「濡れている」と明らかに判別できる時間 は 10 分に満たず、本測定で推定された蒸発比及び蒸発量に対して 表面に滞留する水分の及ぼす影響は小さいものと思われる。

\section{『参考文献】}

1)例えば、村上周三・持田灯・金相進・大岡龍三，関東地域にお ける土地利用状況の変化と流れ場・温度場の関係, 日本建築学 会大会計画系論文集第 491 号, pp.31-39, 1997.1

2)足永靖信・大澤元毅・防垣和明・田中稔・吉村孝信, 保水性建 材を用いた市街地熱環境計画手法の開発その 1 ,その 2, 空気調 和衛生工学会学術講演会講演諭文集 pp.773-780, 1996.9

3)赤川宏幸・小宮英孝, 蒸発冷却を利用した舗装システムの開発, 日本建築学会学術講演梗概集 D-1 環境工学 I， 1998.9

4)白井一義・梅干野晃・堀口剛，透水性孔あきレンガを用いた苲 発泠却壁体の開発, 日本建築学会計画系論文集第 487 号, pp.61-68, 1996.9

5)例えば、新建築学大系 10 環境物理, 彰国社, pp.105-182, 1984 6)例えば、尾崎明仁 : 降水の影響を考慮した建築の熱負荷に関す 万研究、学位論文(九州大学)、1989.12

7) 足永靖信・大澤元毅・坊垣和明・田中稔他 3 名, 保水性建材を 用いた市街地熱環境計画手法の開発その10 UCSS を用いた都市 気温の推定と冷房エネルギー負荷の分析, 空気調和衛生工学会 学術講演会講演論文集而, pp.1417-1420, 1999.9

8)石崎湀雄·光田寧·佐野雄二 : 暴風雨時に壁面に衝突する雨につ いて,京大防災研究所年報 13 号 A,P433-439,1970.3

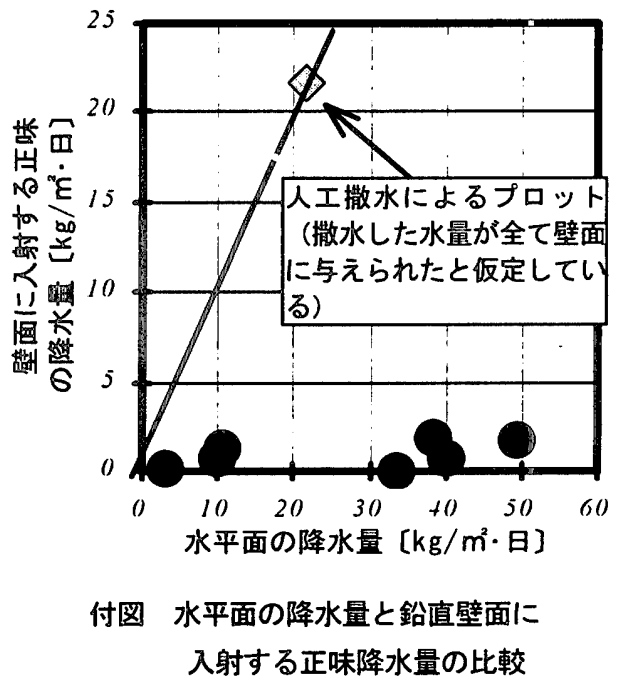

（2000年 1 月 7 日原稿受理， 2000 年 8 月 17 日採用決定） 